\title{
PENGARUH FONEM TERHADAP MORFEM PADA UJARAN ANAK BALITA: SUATU KAJIAN NEURO-MORPHOLOGY
}

\author{
Mhd. Johan ${ }^{1}$, Ika Wijayanti ${ }^{2}$ \\ Program Studi Bahasa dan Sastra Inggris, \\ Fakultas Ilmu Sosial dan Humaniora, Universitas Putera Batam \\ Ithorshid@gmail.com, ${ }^{2}$ ikawy56@gmail.com
}

\begin{abstract}
Abstrak
Penelitian ini bertujuan untuk menjelaskan gangguan morfem yang dialami oleh responden dalam memproduksi morfem. Serta menjelaskan pada lingkungan apa terjadi produksi morfem itu secara fonologi dan neurolinguistik. Untuk mendapatkan data, penulis menggunakan metode simak dengan menggunakan teknik simak libat cakap. Untuk menganalisis data ini penulis menggunakan metode kontribusi dengan teknik bagi unsur langsung dan teknik itu didukung oleh teknik a. Delesi, teknik substitusi, teknik tambah. Hasil yang didapatkan adalah terjadinya gangguan dalam melafalkan fonem, gangguan yang paling dominan terdapat pada saat melafalkan fonem /s/ yang berubah menjadi /c/ pergantian itu terjadi hanya pada lingkungan antepenultima dan penultima gangguan pelafalan fonem /s/ itu tidak terjadi pada akhir morfem.peristiwa ini adalah pergantian pada area yang sama atau satu lingkungan yang sama yaitu pada posisi alveolar voiceless. Kemudian pada saat melafalkan fonem /r/ juga terjadi pergantian dan pelesapan, kalau dia berganti posisi, pergantian itu tetap berada pada satu lingkungan atau area yang sama yaitu liquid plain dan tidak pernah terjadi pada posisi lain. Pelesapan fonem juga terjadi pada saat melafalkan morfem /murni/ menjadi /muni/ sedangkan pada saat menuturkan morfem /magrib/ menjadi /magib/ hal ini juga terjadi pelesapan fonem $/ \mathrm{r} /$.
\end{abstract}

Kata Kunci: Neurolinguistik, Morfologi, Morfem

\begin{abstract}
This study aims to explain the morpheme disorders experienced by respondents in producing morphemes. And explain in what environment the morpheme production occurs phonologically and neurolinguistically. To get the data, the authors use the method of refer to participatory option personal method. To analyze this data the author uses the contribution method with immediate segmenting constituents technique and the technique is supported by techniques. Those are deletions, substitution techniques, and additional techniques. The results obtained are the occurrence of interruption in pronunciation of the phonemes, the most dominant disturbance is when reciting the phoneme $/ s /$ which changes to $/ c /$ the change occurs only in the antepenultima environment and the penultimate phoneme / $/$ / pronunciation disturbance does not occur at the end of the morpheme. this event is a change in the same area or one of the same environment, namely the voiceless alveolar position. Then when pronouncing the phoneme / $r /$ there is also a change and absorption, if he changes position, the changeover remains in the same environment or area that is liquid plain and never occurs in another position. Phoneme infiltration also occurs when pronouncing morphemes / murni / becoming / muni / while when speaking of morpheme / magrib / becoming / magib / this also occurs phoneme / $r$ / phoneme absorption.
\end{abstract}

Keywords: Neuro-linguistics, morphology, morphemes. 


\section{PENDAHULUAN}

Bahasa merupakan sarana komunikasi antar penutur satu dengan penutur yang lainnya dapat juga dilakukan dengan satu masyarakat dengan masyarakat lainnya. Menurut Leung, Purdy, Tippett, \& Leão (2017) bahasa adalah suatu kemampuan yang sangat penting dan sangat komplek, dengan bahasa komunikasi dapat dibangun oleh penutur dan pendengar. Bahasa juga digunakan sebagai alat pemersatu bangsa terbukti dengan adanya bahasa masyarakat Indonesia dapat bersatu untuk melawan penjajah di bumi Indonesia ini. Hal itu dapat dilihat pada naskah sumpah pemuda dengan bunyi "berbahasa satu bahasa Indonesia". Kelihatan sekali fungsi bahasa sebagai alat pemersatu bangsa. Untuk mengaplikasikan bahasa dalam kehidupan sehari-hari sangat diperlukanlah artikulasi. Ujaran-ujaran yang diproduksi dari artikulasi disebut juga dengan fonem. Gabungan satu fonem dengan fonem yang lain itulah yang daisebut dengan morfem sehingga menimbulkan makna. Morfem adalah unit makna kata yang terkecil yang terdiri dari bagian-bagian dari kata.

Untuk menuturkan suatu morfem tidak dapat dilepaskan dari fungsi artikulasi penutur. Menurut Byrd, Mcgill, \& Usler (2015) gangguan fonem lebih dominan pada anak-anak. Gangguan fonem terjadi pada saat responden melafalkan morfem-morfem. Menurut Aichert, Späth, \& Ziegler (2016) pelafalan fonem tidak dapat dipisahkan dari bunyi vokal dan konsonan. Apabila artikulasi berfungsi dengan baik maka baiklah ujaran yang disampaikan ke lawan tutur. Dengan berfungsinya arikulasi sebagaimana yang diharapkan maka lawan tutur akan dapat memahami ujaran-ujaran yang disampaikan itu, sehingga komunikasi antara penutur dengan lawan tutur berjalan dengan baik.

Kegagalan dalam melafalkan fonem akan mempengaruhi makna suatu morfem sehingga lawan tutur tidak memahami apa yang diujarkan oleh penutur sehingga muncul kesalahpahaman antara penutur dengan pendengar. Hal ini membuat peneliti tertarik untuk meneliti ini gangguan pelafalan morfem ini.

Gangguan pelafalan ini tidak hanya dilakukan pada orang dewasa akan tetapi dapat juga dilakukan oleh anak-anak. Gangguan ini lebih banyak dialami oleh anak-anak. Kerbeshian (1988) mengatakan bahwa lebih banyak gangguan bicara dan berbahasa terjadi pada anak-anak. Akibat gangguan pelafalan ini, pesan yang akan disampaikan tidak memenuhi syarat untuk diterima oleh lawan tutur.

Penelitian ini menitikberatkan pada neuro-morphology. Neuro-morphology merupakan gabungan dua unsur ilmu, ilmu yang dimaksud adalah neurolinguistik dan morfologi. Morfologi adalah ilmu yang mempelajari morfem atau dapat juga dikatakan ilmu yang mempelajari unsur pembentukan kata. Ahlsen (2006) mengatakan neurolinguistik, neurologi bahasa dikenal juga neurolinguistik, suatu bidang kajian dalam ilmu linguistik yang membahas struktur otak yang dimiliki seseorang untuk memproses bahasa, termasuk di dalamnya gangguan yang terjadi dalam memproduksi bahasa, kajian ini juga berhubungan dengan komunikasi pada aspek-aspek fungsi bahasa dengan kata lain bagaimana hemisfer itu memahami bahasa dan komunikasi. Kemudian Arifudin (2010) juga memberikan pengertian neurolinguistik. Dia menjelaskan bahwa neurolinguistik menelaah peran otak dalam memperoleh, produksi, pemprosesan, gangguan bahasa dan study interdisipliner tentang kapasitas otak secara umum.

Untuk melafalkan morfem yang benar, seorang penutur harus dapat memfungsikan artikulasi dengan baik dan benar. Dalam istilah morfologi, ada dua morfem, yaitu morfem terikat dan morfem bebas. Morfem terikat yaitu morfem yang tidak dapat berdiri sendiri sedangkan morfem bebas yaitu morfem yang dapat berdiri sendiri. 
Proses berbahasa telah dimulai sejak manusia dilahirkan, seperti yang dikatakan Carstairs Andrew-McCarthy (2002) proses kebahasaan dimulai sejak manusia dilahirkan ke muka bumi ini, proses itu dimulai dari satu morfem. Pada pelafalan morfem banyak hal yang dialami penutur, terutama para penutur balita. Dalam menuturkan ujaran-ujaran yang diproduksi anak balita menjadi hal yang sangat penting dan menarik untuk diteliti. Banyak sekali gangguan dalam melafalkan morfem terjadi pada penutur pemula seperti dalam menuturkan morfem /buku/ menjadi /ku/, /minum/ menjadi /num/ (Johan, 2016). Pada tuturan tersebut anak tersebut tidak dapat melafalkan morfem /buku/ dan morfem /minum/ tataran tuturan yang diujarkannya hanya berada pada tataran penultima.

Penelitian ini sifatnya studi kasus jadi, batasan masalah merupakan salah satu bagian terpenting. Hal ini bertujuan untuk mengerucutkan permasalahan yang akan dibahas dan tidak lari dari jalur topik yang sudah ditetapkan, dalam hal ini penulis membatasi sebatas ujaran-ujaran yang disampaikan oleh responden dalam bertutur. Pembahasan yang akan dibahas itu berkaitan dengan pengaruh bunyi fonem terhadap morfem yang terdapat pada anak berusia di bawah lima tahun.

Formulasi penelitian mengarah pada: Gangguan morfem apa saja yang dialami oleh responden dalam memproduksi morfem-morfem tersebut? Pada lingkungan apa terjadi produksi morfem itu secara fonologi dan neurolinguistik?

Setiap penelitian mempunyai tujuan, hal itu merujuk untuk a) Menjelaskan Gangguan morfem yang dialami oleh responden dalam memproduksi morfem-morfem tersebut, b) Menjelaskan pada lingkungan apa terjadi produksi morfem itu secara fonologi dan neurolinguistik.

Dalam setiap penelitian, seorang peneliti membutuhkan teori. Teori pertama adalah teori neurolinguistik, teori ini digagas oleh Sastra (2010) mengatakan bahwa bicara adalah tahapan perkembangan yang telah sejak bayi. Tahap bicara harus diperhatikan sedini mungkin, karena ternyata dapat dijadikan parameter ada atau tidaknya gangguan perkembangan pada anak. Tentu saja tanpa mengabaikan tahap-tahap perkembangan lain, seperti motorik kasar atau halus dan sosialisasi/interaksi.

Gangguan bicara merupakan keluhan sebagian besar orang tua yang pada akhirnya didiagnosis sebagai gangguan perkembangan multisistem (multisystem developmental disorders). Gangguan ini adalah salah satu bentuk kelainan perkembangan yang muncul dalam gangguan relasi (berinteraksi) dan komunikasi yang akhir-akhir ini terus meningkat. Kegagalan dalam relasi dan komunikasi pada usia 0-3 tahun dianggap sebagai kondisi yang masih dapat berubah dan tumbuh. Hanya saja, mana yang bisa normal perkembangannya dan mana yang akan mengalami gangguan. Oleh karena itu, dua belas bulan pertama kehidupan anak, merupakan masa paling penting untuk mendeteksi tumbuh kembang bicaranya. Berbicara atau berkomunikasi sudah dimulai sejak masa bayi. Normalnya, bayi akan menangis dan bergerak, sehingga seorang ibu dapat belajar bereaksi terhadap tangisan dan gerakannya sehingga terjadi interaksi. Seeorang anak yang mengalami gangguan berbahasa mungkin saja dapat mengucapkan suatu kata dengan jelas, tetapi ia tidak dapat menyusun dua kata dengan baik.

Gangguan komunikasi meliputi berbagai lingkup masalah, yaitu gangguan bicara, bahasa, dan mendengar. Gangguan bahasa dan bicara melingkupi gangguan artikulasi, gangguan mengeluarkan suara, afasia (kesulitan menggunakan kata-kata, biasanya karena memar atau luka pada otak), keterlambatan berbicara atau berbahasa, dan sebagainya.

Gangguan wicara (keterlambatan bicara) pada anak adalah salah satu kelainan yang sering dialami oleh anak-anak dan terjadi pada 1-12 anak atau 5-8\% dari anak-anak prasekolah. Hal ini mencakup gangguan berbicara 3\% dan gagap 1\%. Konsekuensi yang 
diambil pada gangguan tingkah laku, gangguan kejiwaan, kesulitan membaca, dan gangguan prestasi akademik termasuk penurunan prestasi di sekolah sampai drop-out.

Keterlambatan bicara yang terjadi pada anak seorang anak yang perkembangannya dalam bidang normal, jarang disebabkan oleh kelainan fisik, seperti kelainan lidah atau langit-langit di mulut. Anak mengalami keterlambatan berbicara mungkin mengalami masalah motorik oral, artinya ada gangguan dalam pengolahan atau menyampaikan sinyal dari pusat bicara otak. Seorang anak seperti ini akan mengalami kesulitan dalam mengendalikan bibir, lidah, dan rahangnya untuk mengucapkan satu kata.

Faktor-faktor yang menyebabkan keterlambatan bicara pada anak di antaranya adalah:

1. Gangguan Pendengaran

Anak dengan gangguan pendengaran biasanya tidak akan memberi respon terhadap bunyi-bunyi yang ada di sekitarnya. Ganguan ini bisa menyebabkan anak mengalami hambatan pula dalam memahami, meniru dan menggunakan bahasa.

2. Gangguan pada Otot Bicara

Ciri yang paling utama anak yang mengalami gangguan pada otot bicara adalah, lafal bicaranya tidak sempurna, kadang otaknya sudah memerintahkan untuk menjawab dengan benar, tapi yang keluar dari mulutnya tetap tidak jelas. Hal ini terjadi karena adanya gangguan neurologis atau persarafan.

3. Keterbatasan Kemampuan Kognitif

Keterbatasan kemampuan kognitif adalah keterbatasan mempresentasikan objek yang dilihat dalam bentuk image. Bila kemampuan kognitif terganggu, maka image tersebut tidak akan terbentuk. Kondisi ini biasanya bisa dideteksi sendiri oleh orang tua dengan melihat kemampuan motorik anak. Misalnya, anak yang mengalami gangguan bicara biasanya juga kurang mampu melakukan aktivitas lain yang sederhana sekalipun, sepertti memakai sepatu atau mengancingkan baju.

4. Mengalami Gangguan Pervasif

Biasanya terjadi pada anak yang mengalami ADD (attention defisit disorder). Anak yang mengalami keterbatasan atensi ini mengalami masalah di pusat sarafnya, misalnya, pekerjaan tidak pernah tuntas, sulit atau tidak bisa konsentrasi.

5. Kurangnya komunikasi serta interaksi dengan orang tua dan lingkungannya.

Jenis Gangguan Berbicara dan Faktor Penyebabnya, Sidharta dalam Sastra (2010) mengatakan gangguan berbahasa dapat dibedakan atas tiga golongan, yaitu gagguan berbicara, gangguan berbahasa, dan gangguan berpikir. Ketiga gangguan tersebut dapat diatasi kalau penderita gangguan tersebut mempunyai daya dengar normal, bila tidak tentu menjadi sukar. Gangguan berbicara dapat dikelompokan ke dalam tiga kategori, pertama adalah gangguan mekanisme berbicara yang berimplikasi pada gangguan organik, multi faktor, bicara psikogenik.

Sastra (2010) mengatakan lemahnya penguasaan linguistik anak-anak usia dini, lebih banyak ditemukan datanya di lapangan, baik kosa kata, tatabahasa, maupun fonologi. Selain itu ditemukan juga berbagai gangguan berbicara dan gangguan ekspresif. Sejak usia TK atau prasekolah banyak anak-anak yang terakumulasi dalam keterlambatan berbicara, misalnya, gangguan sintaksis dalam menggunakan bentuk-bentuk jamak. Selain itu juga ada gangguan artikulasi (dyslalia), kelalaian, penggantian dan perubahan bunyi (gangguan fonologi).

Secara linguistik, perkembangan bahasa anak dapat dilihat dari dua tahapan, yaitu: Pertama, tahap perkembangan artikulasi seperti bunyi a) resonansi: seperti gerak refleks yang berupa aktivitas kenyutan pada saat menyusui, b) Bunyi berdekut: yaitu bunyi 
konsonan yang berlangsung dalam satu hembusan, c) Bunyi berteler, seperti mengeluarkan bunyi terus-menerus tanpa adanya tujuan, biasanya dilakukan bayi yang berusia empat sampai enam bulan, d. Bunyi berteler ulang, biasanya dilakukan oleh bayi yang berumur enam sampai sepuluh bulan dengan mengucapkan fonem labial $/ \mathrm{b} / \mathrm{dan} / \mathrm{p} /$ bunyi alveolar /t/ dan /d/, bunyi vokabel adalah bunyi yang menyerupai kata, bunyi ini tidak mempunyai arti, dan biasanya dilakukan oleh anak berumur sebelas sampai empat belas bulan.

Kedua, tahap perkembangan kata dan kalimat, terdiri dari a) Kata pertama yang sangat ditentukan oleh penguasan artikulasi, b) Kalimat dari satu kata berawal dari peniruan kata yang sering diucapkan dan didengar anak dari orang dewasa yang terjadi pada anak yang berusia 18 bulan, c) Kalimat dua kata yang pada umumnya bersifat taksa, seperti kata doggie bed yang ditiru dari orang dewasa, d) Kalimat lebih lanjut yang merupakan perluasan kalimat dari kalimat dua kata, seperti agen + aksi $=$ daddy throw, e. Tahap menjelang sekolah, biasanya anak berumur lima atau enam tahun, seperti pendidikan taman kanak-kanak atau play group.

Selanjutnya untuk menganalisis fonem pada suatu ujaran tidak dapat dipisahkan dari fonologi. Pike (1975) mengatakan bahasa terdiri dari bunyi vokal secara sistematis, suara itu berasal dari mulut, hidung, dan tenggorokan. Kemudian menurut Bonvillian (1977) mengatakan bahwa fonologi adalah bidang studi ilmu Bagian-bagian yang alatalat vokal dapat diujarkan oleh penutur untuk menghasilkan kualitas bunyi.

Bunyi juga terdiri dari voiced (bersuara) dan voiceless (tidak bersuara), bergantung pada pita suara, dan tenggorokan. Jika pita suara tertutup, ketika udara keluar, pita suara bergetar dan suara berbunyi; jika mereka terlepas dan tidak bergerak, hasilnya adalah tak bersuara. Voiced dan voiceless yang kontras dapat dijelaskan oleh bagianbagian yang kecil, dua gabungan kata dari dua bunyi adalah sama kecuali pada perbedaanperbedaan yang signifikan.

Kridalaksana (1993) bunyi bilabial dihasilkan dengan penyempitan kedua bibir, dan fonem yang dihasilkan adalah $/ \mathrm{p} /, / \mathrm{b} /$, dan $/ \mathrm{m} /$. Bunyi labio-dental terjadi pada pertemuan bibir bawah dan gigi atas. Bunyi dental terjadi karena penyempitan ruang antara ujung lidah atau lidah dengan gigi. Alveolar terjadi karena penyempitan ruang antara ujung lidah atau daun lidah dan alveolum. Retroflex terjadi karena penyempitan ruang antara ujung lidah yang berkeluk dan alveolum, misalnya: bunyi /t/ dalam bahasa Jawa thukthuk. Bunyi alveo palatal terjadi karena penyempitan lidah depan dan langitlangit depan atau terjadi karena penyempitan antara daun lidah dan alveolum, seperti: syarat. Palatal dihasilkan dengan menempatkan bagian depan lidah di dekat atau pada langit-langit keras. Velar terjadi karena penyempitan antara belakang lidah dan langitlangit lembut, seperti bunyi /k/. Uvular terjadi karena penyempitan antara uvular dan belakang lidah, seperti bunyi /R/. Bunyi faringal terjadi karena penyempitan ruang antara dinding faring dengan akar lidah. Laringal adalah bunyi yang dihasilkan di dalam laring.

Disamping bunyi konsonan ada bunyi lain yang menyertai bunyi tersebut, bunyi itu adalah bunyi vokal. Seperti peta bunyi di bawah ini. Bunyi vokal adalah bunyi yang sangat berpengaruh terhadap produksi suatu kata yang diproduksi oleh seseorang. Apabila seseorang tidak dapat melafalkan bunyi vokal maka makna kata yang diujarkan tidak dapat ditangkap oleh lawan tutur. Teori ini harus melibatkan morfologi.

Morfologi adalah suatu studi tentang morfem dan morfem adalah suatu ilmu linguistik yang menelaah bentuk-bentuk kata beserta bentuk perubahan dari susunan suatu kata yang mempunyai makna Nida (1963). Morfologi tidak dapat dipisahkan dengan fonem. Untuk menelaah data-data ini penulis mempunyai beberapa cara seperti 
memisahkan morfem-morfem dengan membandingkan bentuk-bentuk kata itu. Mendefinisikan morfem berdasarkan morfem-morfem yang diujarkan oleh responden menurut makna dan tujuannyaserta menganalisis morfem secara segmental. Di samping itu menelaah kapan terjadinya fonem-fonem yang dilafalkan oleh responden secara fonologi, kemudian penulis juga menganalisis hubungan morfem satu dengan bentukbentuk morfem lain. Nida (1963).

Penelitian ini pernah dilakukan oleh Hartanto, Selina, H, \& Fitra (2011), mengatakan bahwa bahasa salah satu indikator perkembangan kognitif anak. Mereka mengatakan perkembangan anak sangat menentukan keberhasilan dalam memaksimalkan plastisitas otak pada kompensasi penyimpangan perkembangan. Tujuan penelitian itu adalah untuk mengetahui pengaruh perkembangan bahasa terhadap perkembangan kognitif anak usia 1-3 tahun.

Selanjutnya penelitian seperti ini pernah juga dilkukan oleh Winarsih (2012). Winarsih melakukan penelitian ini pada anak tuna rungu dalam beriteraksi. Judul desertasinya adalah "expresi tutur anak tuna rungu dalam interaksi di kelas", Universitas Negeri Malang.

Setelah itu Dewi (2013). dalam penelitian itu dia meneliti seorang anak laki-laki yang mengalami gangguan dalam bicara. Dengan judul "Disfungsi Bahasa Anak Retardasi Mental Ringan: Studi Kasus, Pada Tuturan Yogi”. (tesis S2): Pascasarjana Universitas Andalas.

Kemudian Johan (2016) melakukan penelitian dengan judul Gangguan Pelafalan Fonem Terhadap Anak-Anak (balita) suatu kajian: Neurolinguistik. Johan dan Suri (2019) dalam penelitiannya menemukan proses penghilangan, proses penambahan, dan proses ganti pada tuturan anak-anak..

\section{METODE PENELITIAN}

Di sini peneliti melakukan penelitian di kota di mana peneliti tinggal, Sehubungan dengan segala keterbatasan, seperti, keterbatasan biaya dan waktu, maka penelitian ini dilakukan di sekitar kota Batam. Dalam melakukan penelitian ini penulis menggunakan metode.

Metode simak libat cakap (SLC) sangat pantas digunakan untuk penelitian ini, di mana, peneliti ikut terlibat dalam memancing responden untuk bicara sebanyak-banyak, kemudian peneliti merekam ujaran yang diujarkan oleh responden secara diam-diam. Dalam mendapatkan data peneliti melakukan teknik berikut.

Teknik lanjutan mempunyai beberapa tahapan. Tahapan itu terdiri dari teknik simak libat cakap, teknik rekam, dan teknik catat.

Penelitian ini akan dijelaskan secara deskriptif, kalaupun ada tabel itupun bentuknya hanya sederhana. Penelitian seperti ini, masih dianggap penelitian deskriptif kualitatif. Karena bentuk sangat mudah dibaca. Dan tidak membutuhkan hitunganhitungan secara statistik. Metode dan teknik analisis yang digunakan adalah metode agih dan dilanjutkan dengan teknik dasar dan teknik lanjutan oleh Sudaryanto (2015).

Penelitian ini adalah penelitian kualitatif, subjek penelitian ini adalah tuturan anak-anak yang berusia di bawah tiga tahun. Anak-anak ini mengalami masalah dalam melafalkan fonem yang digunakan dalam wicara setiap harinya. Perkembangan saraf motorik wicara anak-anak ini belum berkembang seperti anak-anak yang yang dapat bicara normal. Sebanarnya anak-anak tersebut dapat berbicara dengan lincahnya tetapi ujaran-ujaran yang diujarkannya tidak tepat sebagaimana yang diharapkan. 
Anak-anak yang berumur di bawah tiga tahun itu melafalkan kata-kata tidak sempurna. Kata-kata yang dilafalkan kadang-kadang berada pada tataran penultima dan ultima. Seperti morfem /buku/ menjadi /ku/. Di lain sisi anak-anak melafalkan kata-kata dengan menghilangkan fonem pada tengah-tengah kata. Seperti: /bicara/menjadi /bicala/ atau /bisa/ menjadi /bica/.

Berhubung penelitian ini sangat berhubungan dengan tuturan kata yang diujarkan oleh responden, maka subjek penelitian ini berfokuskan ke pada tataran morfologi. Cara anak-anak mengujarkan fonem-fonem tersebut sangat berhubungan dengan neurolinguistik. Neurolinguistik adalah suatu kajian ilmu bahasa bagaimana cara manusia memperoleh bahasa. Data ini diambil ketika anak-anak sedang bermain, bergurau, bersantai. Penelitian ini dilakukan di rumah responden dan saat-saat mereka diluar rumah. Peneliti sengaja menyiapkan beberapa kata yang dapat mewakili penelitian ini. Adapun waktu penelitian ini dilakukan pada waktu-waktu senggang.

\section{HASIL DAN PEMBAHASAN}

Pada bagian ini, peneliti mencoba untuk menjelaskan hasil yang telah di peroleh selama penelitian berlangsung. Semua data yang telah didapatkan di sini akan dijelaskan sesuai dengan ilmu yang peneliti peroleh. Analisis ini akan dianalisis berdasarkan intuisi dan kemampuan yang dimiliki yang dalam, yang sesuai dengan ilmu linguistik, khususnya neurolinguistik dan didukung dengan ilmu morfologi.

Tabel 1 Data Responden

\begin{tabular}{|c|c|c|c|c|c|c|}
\hline No. & $\begin{array}{c}\text { Jenis } \\
\text { Kata } \\
\text { Yang } \\
\text { Akan } \\
\text { Diujarkan }\end{array}$ & $\begin{array}{c}\text { Jenis } \\
\text { Kata } \\
\text { Yang } \\
\text { Diujarkan }\end{array}$ & $\begin{array}{l}\text { Jenis Gangguan } \\
\text { Pelafalan }\end{array}$ & $\begin{array}{c}\text { Perubahan } \\
\text { Pelafalan }\end{array}$ & $\begin{array}{l}\text { Pelesapan } \\
\text { Fonem }\end{array}$ & $\begin{array}{c}\text { Tidak } \\
\text { Beraturan }\end{array}$ \\
\hline 1 & baca & baca & - & & & \\
\hline 2 & murni & muni & murni > muni & & $/ \mathrm{r} /$ & \\
\hline 3 & kaca & kaca & - & & & \\
\hline 4 & bara & bara & - & & & \\
\hline 5 & kotak & otak & kotak>otak & & $/ \mathrm{k} /$ & \\
\hline 6 & bisa & bica & & $\mathrm{s}>\mathrm{c}$ & & \\
\hline 7 & bantu & batu & bantu $>$ batu & & $/ \mathrm{n} /$ & \\
\hline 8 & siapa & ciapa & & $s>c$ & & \\
\hline 9 & magrib & magib & magrib>magib & & $/ \mathrm{r} /$ & \\
\hline 10 & mushola & cumola & mushola $>$ cumola & & & cumola \\
\hline 11 & lurah & lurah & - & & & \\
\hline 12 & enak & enak & - & & & \\
\hline 13 & kamu & kamu & - & & & \\
\hline 14 & sekolah & cekolah & sekolah>cekolah & $\mathrm{s}>\mathrm{c}$ & & \\
\hline 15 & ramai & lamai & ramai>lamai & $r>1$ & & \\
\hline 16 & susah & cucah & susah>cucah & $s>c$ & & \\
\hline 17 & senang & cenang & senang>cenang & $s>c$ & & \\
\hline 18 & sebelas & cebelas & sebelas>cebelas & $s>c$ & & \\
\hline 19 & rok & rok & - & & & \\
\hline 20 & sisa & cica & sisa $>$ cica & $s>c$ & & \\
\hline
\end{tabular}




\begin{tabular}{|c|c|c|c|c|c|}
\hline 21 & sayur & cayur & sayur>cayur & $s>c$ & \\
\hline 22 & sagu & cagu & sagu>cagu & $s>c$ & \\
\hline 23 & susu & cucu & susu>cucu & $s>c$ & \\
\hline 24 & guru & guru & - & & \\
\hline 25 & geraham & geraam & gerahan>geraam & & $/ \mathrm{h} /$ \\
\hline 26 & mainan & mainan & - & & \\
\hline 27 & perawat & pewawat & perawat>pewawat & $r>w$ & \\
\hline 28 & $\begin{array}{l}\text { rumah } \\
\text { sakit }\end{array}$ & $\begin{array}{l}\text { rumah } \\
\text { cakit }\end{array}$ & $\begin{array}{l}\text { rumah sakit> } \\
\text { rumah cakit }\end{array}$ & $s>c$ & \\
\hline
\end{tabular}

Mengamati data yang dilafalkan oleh responden di atas ada hal yang paling dominan yang sangat sukar diujarkan oleh responden tersebut. Masalah yang pertama muncul pada saat melafalakan bunyi fonem /s/. Ujaran fonem /s/ yang diujarkan oleh responden ada sebanyak 16 (enam belas) ujaran. Posisi Fonem /s/ yang diujarkan oleh responden berada pada posisi ante penultima, penultima, dan ultima. Fonem /s/ itu berada pada posisi antepenultima ada sebanyak 10 ujaran, sementara ujaran yang berada pada penultima ada 5 ujaran, sedangkan pada ultima ada 1 ujaran. Ujaran tersebut terlihat pada tabel di bawah ini.

Berdasarkan persentase yang paling dominan adalah pada posisi antepenultima dengan 63 persen dari $10: 16 \times 100 \%=69 \%$. Sementara itu persentase pada penultima adalah $5: 16 \times 100 \%=31 \%$, sedangkan untuk ujaran ultima berada pada persentase $0: 16$ $\mathrm{x} 100 \%=0 \%$. Persentase tersebut dapat digambarkan sebagaimana tabel di bawah ini:

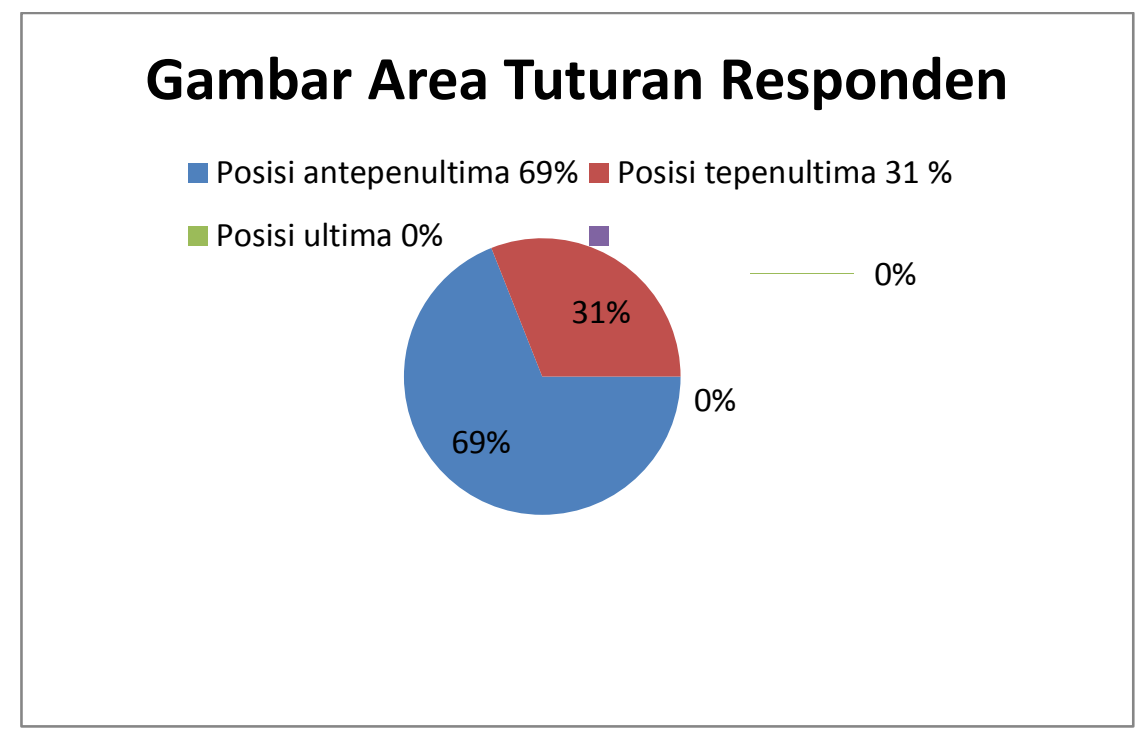

Gambar 1 Persentase Tuturan Fonem /s/

Ujaran-ujaran yang dituturkan oleh responden tersebut merupakan pergantian bunyi fonem. Pergantian bunyi fonem tersebut adalah pergantian fonem /s/ dengan fonem /c/. Hal tersebut merupakan pergantian dalam lingkungan yang sama yaitu fricative alveolar voiceless /s/ dengan africative alveolar voiceless /c/.

Masalah ujaran lainnya terjadi pada ujaran fonem $/ \mathrm{r} /$, pada ujaran fonem $/ \mathrm{r} /$ ini penulis dapatkan responden mengalami gangguan dalam menuturkannya. Pada melafalkan morfem /murni/ responden melafalkan /muni/ sehingga terjadi penghilangan 
fonem /r/. Kemudian pada pelafalan morfem /magrib/ juga mengalami masalah, masalah itu adalah pelesapan fonem /r/. Di samping itu peneliti juga menjumpai substitusi pada morfem, subsitusi itu terjadi pada morfem /ramai/ dan /perawat/. Bunyi fonem /r/ pada kedua morfem tersebut berganti menjadi /l/ pada /ramai/ dan /w/ pada /perawat/. Pergantian fonem tersebut terjadi pada satu lingkungan yang sama. Lingkungan tersebut adalah lingkungan liquid rhotic plain, liquid lateral plain dan liquid glide plain. Dengan kata lain posisi lingkungan itu adalah pada posisi liquid plain.

Tabel 2 Pelafalan Fonem /r/

\begin{tabular}{|c|c|c|c|c|c|c|c|}
\hline \multirow{2}{*}{ Nomor } & \multirow{2}{*}{$\begin{array}{l}\text { Nama } \\
\text { Ujaran }\end{array}$} & \multirow{2}{*}{$\begin{array}{c}\text { Ujaran } \\
\text { Responden }\end{array}$} & \multirow{2}{*}{$\begin{array}{l}\text { Tidak } \\
\text { Berubah }\end{array}$} & \multirow{2}{*}{ Pelesapan } & \multicolumn{3}{|c|}{$\begin{array}{l}\text { Substitusi Fonem Pada } \\
\text { Posisi Liquid }\end{array}$} \\
\hline & & & & & $\begin{array}{l}\text { Rhotic } \\
\text { Plain }\end{array}$ & $\begin{array}{l}\text { Lateral } \\
\text { Plain }\end{array}$ & $\begin{array}{l}\text { Glide } \\
\text { Plain }\end{array}$ \\
\hline 1 & murni & /muni/ & & $\checkmark$ & & & \\
\hline 2 & magrib & /magib/ & & $\checkmark$ & & & \\
\hline 3 & lurah & /lurah/ & $\checkmark$ & & & & \\
\hline 4 & ramai & /lamai/ & & & & $\checkmark$ & \\
\hline 5 & rok & /rok/ & $\checkmark$ & & & & \\
\hline 6 & sayur & /sayur/ & $\checkmark$ & & & & \\
\hline 7 & guru & /guru/ & $\checkmark$ & & & & \\
\hline 8 & geraham & /geraam/ & $\checkmark$ & & & & \\
\hline 9 & perawat & /pewawat/ & & & & & $\checkmark$ \\
\hline
\end{tabular}

Pelafalan-pelafalan morfem yang terjadi pada tabel di atas menimbulkan tiga peristiwa, yaitu peristiwa tidak berubah, pelesapan dan pergantian (substitusi). Selanjutnya proses substitusi terjadi pada lingkungan yang sama yaitu masih pada area liquid, baik liquid lateral plain maupun liquid glide plain.

Peristiwa pergantian, penghilangan, dan berubah dapat dideskripsikan sebagai berikut: bunyi /r/ yang bersebelahan dengan fonem /a/ "rendah pusat" pada posisi antepenultima mengalami masalah, hal itu terbukti ketika responden melafalkan morfem pada: morfem /ramai/ menjadi /lamai/ proses ini disebut dengan proses ganti. Selanjutnya, bunyi /r/ yang bersebelahan dengan bunyi $/ \mathrm{o} /$ " tengah belakang bundar" dapat diujarkan dengan baik. Posisi pergantian pada fonem /r/. lingkungan liquid rhotic plain /r/ menjadi liquid lateral plain /1/.

Persentase peristiwa pada posisi antepenultima terdapat 1 proses ganti yaitu /ramai/ menjadi /lamai/. Sementara itu pada posisi tengah terdapat proses penghilangan sebanyak 2 kali. Yang terdapat pada morfem /murni/ menjadi /muni/, /magrib/ menjadi /magib/. Kemudian proses ganti terdapat satu kali yang terdapat pada morfem /perawat/ menjadi /pewawat/. Sementara itu pada posisi belakang morfem tidak terjadi perubahan, seperti: pelesapan dan pergantian. Hal itu kelihatan pada morfem /sayur/. Persentase fonem /r/ yang terjadi pada 9 morfem dapat digambarkan pada tabel di bawah ini. 


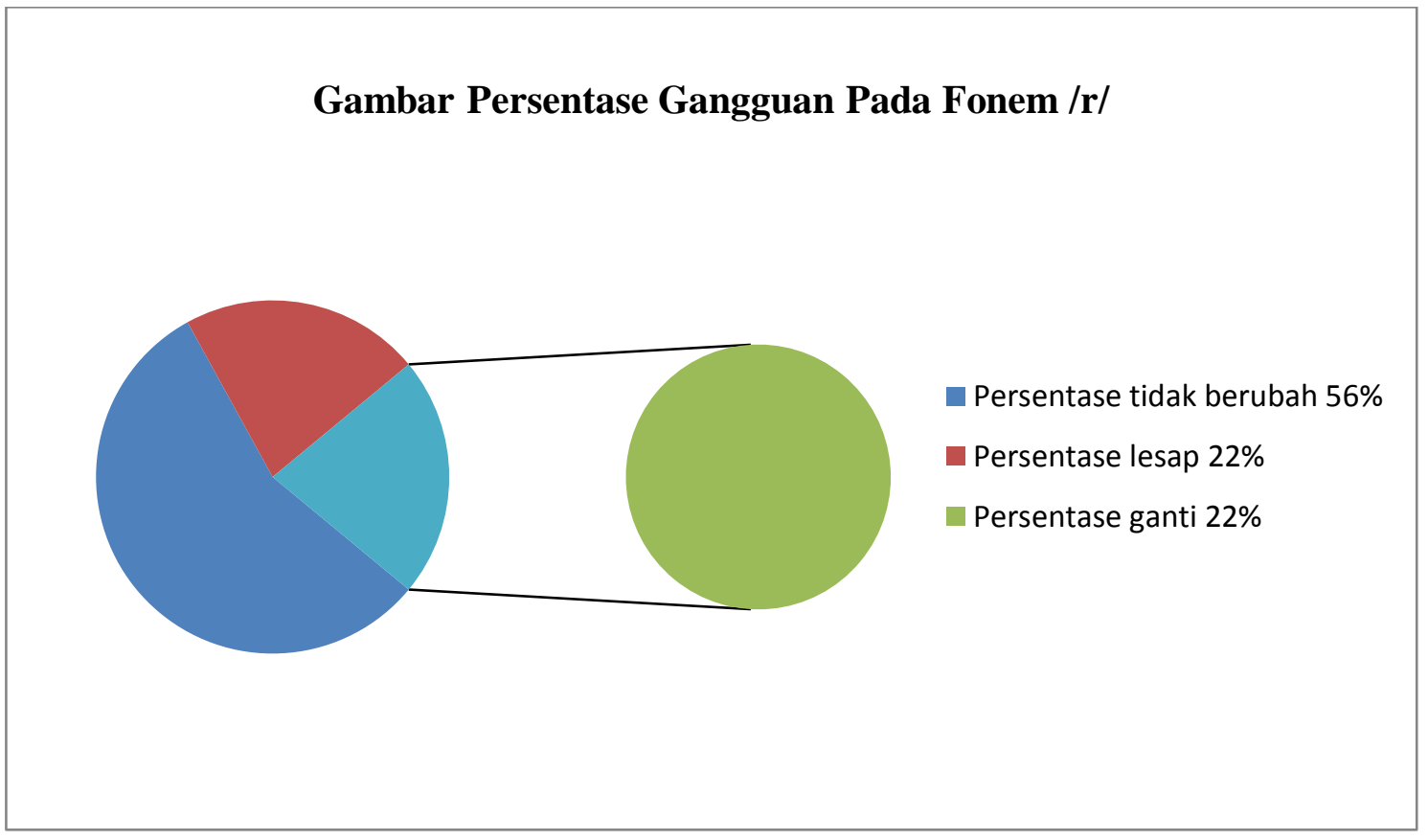

Gambar 2 Persentase pada Fonem /r/

Tuturan lain yang mendapati masalah adalah bunyi konsonan $/ \mathrm{k} /$. Pada data di atas, terdapat delapan bunyi fonem $/ \mathrm{k} /$. Diantaranya adalah: $/ \mathrm{kaca} / \mathrm{ada}$ satu bunyi fonem $/ \mathrm{k} /$, /kotak/ terdapat dua fonem $/ \mathrm{k} /$, /enak/ ada satu fonem $/ \mathrm{k} /$, /kamu/ terdapat satu fonem /k/, /sekolah/ ada satu fonem /k/, /rok/ juga satu fonem /k/ yang terakhir adalah fonem /k/ pada morfem /sakit/.

Di antara tujuh pelafalan morfem yang diujarkan oleh responden terdapat delapan fonem $/ \mathrm{k} /$. Dari delapan fonem itu ada satu fonem $/ \mathrm{k} /$ yang tidak dapat dilafalkan oleh responden yaitu pada morfem /kotak/ menjadi /otak/. Menurut pengamatan penulis, morfem /k/ yang dilafalkan responden dianggap tidak mengalami gangguan sebab dari delapan ujaran yang dilafalkan tersebut hanya satu yang mengalami gangguan. Hal ini boleh dikatakan responden tidak mengalami masalah dalam melafalkan fonem $/ \mathrm{k} /$.

Setiap morfem yang mau diujarkan sebenarnya sudah dikonsep pada hemisfer kanan responden, akan tetapi adakalanya hemisfer kanan dan hemisfer kiri tidak berjalan secara seimbang. Hal tersebut dapat dipengaruhi oleh saraf pada hemisfer kiri responden. Saraf bicara manusia itu terdapat pada hemisfer kiri dan keseimbangan bicara itu dapat dikendalikan oleh hemisfer kanan responden, sehingga produksi ujaran yang disampaikan tidak beraturan. Morfem yang diujarkan oleh responden tersebut ketika saat mengujarkan /mushola/ menjadi /cumola/. Ketidakteraturan tersebut dapat dipengaruhi oleh bunyi fonem /s/ karena responden tidak dapat melafalkan bunyi fonem /s/ dengan sempurna.

\section{SIMPULAN}

Morfem yang diproduksi seorang anak sering mengalami masalah, masalah yang diujarkan tersebut tidak dapat dilepaskan dari pengaruh hemisfer kiri dan kanannya. Ada masalah pelafalan morfem yang paling dominan yaitu pada pelafalan fonem /s/ menjadi /c/. Gangguan pelafalan tersebut terdapat pada posisi antepenultima dan penultima, secara persentase dari gangguan tersebut adalah $69 \%$ pada posisi antepenultima, $31 \%$ pada posisi penultima, dan $0 \%$ untuk ultima. Sementara untuk pelafalan fonem $/ \mathrm{r} /$ terjadi perubahan produksi bunyi fonem. Perubahan-perubahn itu terjadi pada satu lingkungan, 
lingkungan itu adalah lingkungan liquid atau liquida. Lingkungan perubahan itu tetap pada lingkungan liquid plain. Persentase gangguan fonem $/ \mathrm{r} /$ itu adalah tidak berubah $56 \%$, lesap $22 \%$, dan subtitute $22 \%$.

Penelitian ini merupakan penelitian linguistik terapan, semua data yang muncul di sini adalah murni dari ujaran-ujaran responden. Ujaran yang ditimbulkan oleh responden tersebut didapat secara fenomena. Untuk mewujudkan adanya komunikasi antara responden dengan orang tua maka penulis menyarankan pada peneliti berikut untuk melanjutkan penelitian ini dengan judul yang lain.

\section{DAFTAR PUSTAKA}

Ahlsen, E. (2006). Introduction to neurolinguistics. Amsterdam: John Benjamins Publishing Company.

Aichert, I., Späth, M., \& Ziegler, W. (2016). The role of metrical information in apraxia of speech. Perceptual and acoustic analyses of word stress. Neuropsychologia, 82, 171-178. https://doi.org/10.1016/j.neuropsychologia.2016.01.009

Arifudin. (2010). Neuro psikolinguistik. Jakarta: Rajawali Pers.

Bonvillian, N. (1977). Language, culture and communication: The meaning of messages. New Jersey: Prentice-Hall, Inc.

Byrd, C. T., Mcgill, M., \& Usler, E. (2015). Nonword repetition and phoneme elision in adults who do and do not stutter: Vocal versus nonvocal performance differences. Journal of Fluency Disorders, 44, 1-15. https://doi.org/10.1016/j.jfludis.2015.01. 004

Carstairs Andrew -McCarthy. (2002). An introduction to English morphology: words and their structure. EdinburghUniversity Press.

Dewi, Y. K. (2013). Disfungsi bahasa anak retardasi mental ringan: Studi kasus pada tuturan Yogi. Universitas Andalas.

Hartanto, F., Selina, H., H, Z., \& Fitra, S. (2011). Pengaruh perkembangan bahasa terhadap perkembangan kognitif anak usia 1-3 Tahun. Sari Pediatri, 12(6), 388389.

Johan, Mhd., \& Suri, S. R. (2019). Spesch disorder for the children under three years old: The study of neurolinguistics. Gramatika, 5(1).

Johan, M. (2016). Gangguan pelafalan fonem terhadap anak-anak (balita) suatu kajian: Neurolinguistik. BASIS, 4(1).

Kerbeshian, J. (1988). A role for biogenic amines in developmental language disorders, 12, 289-293.

Kridalaksana, H. (1993). Kamus linguistik. Jakarta: PT Gramedia. 
Leung, J. H., Purdy, S. C., Tippett, L. J., \& Leão, S. H. S. (2017). Affective speech prosody perception and production in stroke patients with left-hemispheric damage and healthy controls. Brain and Language, 166, 19-28. https://doi.org/ 10.1016/j.bandl.2016.12.001

Nida, E. A. (1963). Morphology: The descriptive analysis of words (second edi). Michigan: The University of Michigan Press.

Pike, K. L. (1975). Phonemics: A technical for reducing languages to writing. Michigan: The University of Michigan Press.

Sastra, G. (2010). Neurolinguistik: Suatu pengantar. Bandung: Alfabeta Bandung.

Sudaryanto. (2015). Metode dan aneka teknik analisis bahasa: Pengantar penelitian wahana kebudayaan secara linguistis. Yogyakarta: Sanata Dharma University Press.

Winarsih, S. (2012). Ekspresi tutur anak tuna rungu dalam interaksi di kelas. Universitas Negeri Malang. 